\title{
Documenta
}

\section{Seminário Shakespeare}

Marcus Mota

Revista do Laboratório de Dramaturgia - LADI - UnB - V. 1, Ano 1 


\title{
Notas sobre peças de Shakespeare
}

\author{
Marcus Mota \\ Universidade de Brasília \\ Laboratório de Dramaturgia(LADI) \\ marcusmotaunb@gmail.com
}

Resumo: Aqui se reúnem ensaios e notas sobre peças de Shakespeare, escritos entre 1995 e 2007 para o Seminário Shakespeare. As obras estudadas são Tito Andrônico, Noite de Reis, Tróilo e Cressida, Comédia de Erros e Rei Lear.

Palavras-chave: Shakespeare, Dramaturgia, Comicidade, Hermenêutica.

Abstract: Here are are presented and collected essays and notes based on Shakespeare's Plays. These texts were written from 1995 to 2005 as material to the Seminar on Shakespeare. The plays that were studied and analysed are: Titus Andronicus, Twelfth Night,Troilus and Cressida, The Comedy of Errors, King Lear.

Keywords: Shakespeare, Dramaturgy, Comicity, Hermeneutics.

\section{0 - Apresentação}

Entre 1995 e 2007 ministrei no Departamento de Artes Cênicas da UnB a disciplina 'Literatura Dramática' III, que, a partir da análise de textos cênicos, buscava o estudo de repertório europeu em autores como Lope de Vega, Calderón de La Barca, Racine, Moliére e, claro, Shakespeare. A partir de um certo tempo, transformei, por opção, o curso em uma espécie de 'Seminário Shakespeare': a cada semestre sete peças do bardo inglês eram estudadas.

Durante esse tempo, elaborei alguns pequenos textos que publiquei em um site que disponibilizava minha produção artística e intelectual. Estes textos ou notas eram ideias advindas a partir da preparação e aplicação das aulas de análise textual. Seriam materiais para um futuro livro nunca escrito sobre análise de textos teatrais.

Muitos desses textos se perderam em função de problemas que tive com o fechamento da empresa responsável por meu site. Os textos aqui reunidos estão em ordem temporal inversa - dos mais recentes aos mais antigos. O que se pode observar é uma mudança de foco e de vocabulário que registra mudanças mesmas no LADI: como minha experiência era mais em análise de textos literários, os primeiros textos expressam questões e métodos oriundos de minhas pesquisas em imaginação literária a partir de Gaston Bachelard ${ }^{1}$.

1 V. minha dissertação de mestrado A Hermenêutica da Imaginação em Adonias Filho (UnB, 2002), agora reescrita e incluída na primeira parte do livro Imaginação e Morte. Ensaios sobre a Representação da Finitude (Editora UnB,2014). 
A partir de um maior contato com a diversidade multitarefa de eventos cênicos, comecei a reelaborar estratégias de leitura e interpretação de textos teatrais.

Algo, porém, que sempre me determinou foi produzir textos que não fossem explicações das obras analisadas. Isto é, meu diálogo era com algum aspecto da organização do texto estudado ${ }^{2}$.

\section{1 - Titus Andrônicus: Violência, Morte e Espetáculo ${ }^{3}$}

Mas isso é Shakespeare?

Mesmo hoje, a carnificina de Titus Andronicus coloca em questionamento a busca de um padrão estético para uma produção tão variada como a do bardo. O excesso contra o corpo, em mutilações, estupro, sacrifícios, assassinatos e canibalismo desafia sensibilidades que buscam seu prazer na contemplação e reprodução de esquemas narrativos. $\mathrm{O}$ que parece incomodar muitos críticos é o fato de aquilo que se mostra em sua brutalidade venha a ser considerado 'teatro' T.S. Eliot chegou, no século passado, a dizer que Titus Andronicus era uma das mais estúpidas e menos inspiradas coisas já escritas ${ }^{4}$. Já H. Bloom, afirma que a peça foi fundamental para o aprendizado do dramaturgo, para Shakespeare somente, e não para nós 5 .

Essa visão negativa, excludente nos impulsiona para um limite, para aquilo que não se quer aceitar. $\mathrm{O}$ ciclo de sangue e morte que atravessa a peça foi atraente para os espectadores da época e continua sendo um recurso em obras das mais variados gostos. $\mathrm{Ou}$ seja, como entretenimento, morrer e matar são atos que marcam parâmetros de composição e recepção de espetáculos. O aparente arcaísmo das mortes em Titus Andronicus nos revela uma abordagem que escapa de nossos hábitos de representar a morte, da morte domada, da morte como convenção ${ }^{6}$. No excesso está a violência não justificada, não admitida dentro das violências socialmente possíveis. O grotesco e quase cômico 'terrir' (terror como rir) da peça ressalta como nos é inconfortável acompanhar uma sequência de atos que ultrapassam a medida de sua pressuposta finalidade.

O caos de Roma, da Roma da peça, é instaurado pela recusa de Titus, valoroso guerreiro como Coriolano, em aceitar ser coroado Imperador. Em seu lugar assenta-se um

2 Comento mais tais estratégias em "Dramaturgia, colaboração e aprendizagem: um encontro com Hugo Rodas" In: Histórias do Teatro Brasiliense. Brasília:IdA/UnB, 2003, p. 198-217). Sobre tais estratégias hermêuticas, v. H.G. Gadamer (Verdade e Método. Petrópolis:Vozes,1997).

3 Escrito em 21/10/2007.

4 "One of the stupidest and most uninspired plays ever written", no ensaio 'Seneca in Elisabethan translation' In Selected Essays 1917-1932 (Nova York: Harcourt,Brace and Company 1934,p.23).

5 Shakespeare: A invenção do Humano (Objetiva,2000).

6 Sobre o tema, v. "O narrador", de Walter Benjamin In Magia e Técnica, arte e política.Ensaios sobre literatura e história da cultura. (São Paulo: Brasiliense,1994,p. 197-221); e os dois volumes de O Homem diante da morte, de P. Ariès ( Rio de Janeiro: Francisco Alves, 1989). 
soberano tolo, manipulado por uma vingativa rainha de povos bárbaros, Tamora, esta manipulada por um amante monstruoso e armador de perfídias, o mouro Aarão. Como se vê, parece uma antologia de tipos famosos...

A vingança de Tamora toma a primeira parte da peça. Ela responde a morte de seu filho, incinerado em ritual de sacrifício para aplacar os deuses. O filho de Tamora fora estripado, seus membros cortados, suas entranhas postas para arder no fogo. Titus, o homem do dever-fazer, não ouve as súplicas de Tamora. Os atos II e III vão consumar essa vingança desproporcional: a filha de Titus, Lavínia, estuprada e mutilada (as mãos e a língua cortadas), dois filhos de Titus mortos (cabeças cortadas) e o próprio Titus com tendo decepado uma de suas mãos para tentar salvar os filhos.

A segunda vingança ocupa os dois atos finais. Habilmente, Shakespeare inicia por cenas amenas essa nova etapa da peça, adiando as mortes esperadas. $\mathrm{O}$ adiamento dilata-se em uma brincadeira com a morte, na qual a rainha Tamora, como uma feiticeira, vai ao encontro de Titus, fantasiada de uma divindade ctônica - Vingança - assistida por seus dois filhos-auxiliares, Estupro e Assassinato. O jogo entre o disfarce e o desmascaramento é tão explícito que tudo se transforma em absurdo, emendando nas mortes finais, até a de Titus, o personagem que dá nome à peça.

Enfim, tudo tem que morrer para ser atrativo. A generalizada mútua violência segue outra racionalidade, outra explicação. $\mathrm{O}$ excesso aponta para uma ultrapassagem, para uma 'a mais', para uma diferente lógica, vinculada ao espetáculo. Ao planejar e impetrar as mortes, as personagens exibem um poder-fazer que não acata restrições e demandas outras que as ditadas por uma estrita ratificação daquilo que é sabido e partilhado. Aplicando-se ao rigor de seguir àquilo que a elas se impõe, as figuras em cena não mais partilham de valores que supomos haver em uma pessoa. Daí nosso desconforto e negação. Essas máquinas de matar parecem distantes de nós, de nossa civilização, de nosso repertório. $\mathrm{O}$ que nos resta, com Titus Andronicus, é parar de perseguir a projeção humanizante, e acompanhar o estranho, seu vulto, sua voz, mesmo entre os nacos de carne e a tortura.

\section{2 - Dramaturgia de Noite de Reis: Teatralidade e Comicidade ${ }^{7}$}

Começando pelo título - $A$ décima segunda noite. O título refere-se à festividade que celebra o encontro dos reis magos com o menino Jesus, doze dias depois de seu nascimento. Um menino pobre saudado como rei, Deus virando criança - uma série de transformações que colocam o mundo ao avesso. Daí a folia, folia de reis, reisado ("dança rápida ao som do pandeiro; folgança ruidosa;pândega” no século XVI ${ }^{8}$ ), do francês folie,

7 Texto elaborado em 25/09/2007. Este texto e o n. 4 integram um conjunto de pesquisas sobre a dramaturgia cômica. V. MOTA, M. "Dramaturgia e Comicidade: notas de pesquisa. In: Da cena Contemporânea. Porto Alegre: Abrace/UFRGS, 2012, p. 72-81.

8 CUNHA,A.G. Dicionário Etimológico. Nova Fronteira, 1987. 
'loucura,' 'desvario",tolice,' 'asneira', 'mania'.

O subtítulo - "o que você quiser " (What you Will) - expande essa dimensão de festa dos disfarces na qual aquilo que é, é apenas aquilo que parece ser - uma máscara. Agora, além disso, ser é querer, mas não se atinge o que se quer.

Para além de um polemismo metafísico, a relação entre aparências e desejos exibe e enfatiza a metateatralidade do espetáculo, o espetáculo mostrando-se como armação, como arranjo.

A peça organiza-se em uma série de distintas e distinguíveis trajetórias de personagem, as quais entram em rota de colisão, expondo os diferentes projetos, fantasias de cada uma das trajetórias ${ }^{10}$. A comicidade está justamente entre reunir os díspares. Nos encontros, os reunidos mais se distanciam e se opõem. Como Shakespeare trabalha com a cena pivotal (há um centro de cena, um foco principal; e a margem, foco secundário), quando as trajetórias díspares convergem no mesmo espaço-tempo da cena, a expectativa de harmonização, de acordo é trabalhada de modo a se ampliar aquilo que já era assimétrico. Ou seja, a dramaturgia de Shakespeare aqui apresenta para o público trajetórias com potencial de conflito e acerto ou hegemonia. Porém, quanto essas trajetórias são reunidas em cenas convergentes, aquilo que antes já era assimétrico passa a ser mais antitético, como em um arremesso - a proximidade dos díspares revela-se em distância hiperbólica, impossibilidade de homogeneização. O acordo, a simetria adiados, configura o espetáculo até sua conclusão.

Então temos 1- apresentação das trajetórias assimétricas; 2- momentos de sincronização dessas trajetórias e intensificação das disparidades; 3-resoluções breves, às vezes inauditas, dessa intensificação.

Os disfarces e os duplos conectam esse ritmo de trajetórias díspares à manifesta teatralidade do espetáculo. A comicidade produz seus efeitos pela identificação das assimetrias entre as personagens, traduzidas em desníveis cognitivos: as personagens não sabem o que está acontecendo, quem está diante delas. Ou seja, não se aplica aos agentes de cena uma verossimilhança estreita, como se fossem pessoas aqueles que no palco agitam-se. Contracenando frontalmente com travestidos, com personagens disfarçados, as personagens contribuem não para seu conhecimento do que está acontecendo. É preciso ter em mente que o disfarce é um expediente direto é claro: uma personagem disfarçada em cena não passa de uma personagem disfarçada em cena. $\mathrm{O}$ acúmulo e sobreposição de informações não se dirigem para os agentes dramáticos e sim para a platéia. Como os mascarados, a platéia se vê cumulada de informações. O não saber da personagem reforça

9 Em sisuda nota introdutória à sua tradução (Aguilar, 1989), Oscar Mendes afirma que "O título da comédia não possui qualquer relação com o assunto. Twelfth Night ou Décima-segunda noite se refere ao fato de haver sido apresentada pela primeira vez na décima segunda noite depois do natal, ou seja, na festa da Epifania ou Dia de Reis".

10 Temos: 1 - Orsino; 2 - Viola/Sebastião; 3 - Olívia; 4 - Malvólio; 5 - Tobias, Andrew, Maria; 6 Feste, o bobo. 
o conhecimento que a audiência tem do que está acontecimento. A limitação da perspectiva da personagem amplia a perspectiva da platéia. Ao saber mais, a audiência vincula os atos em cena não apenas ao momento de sua realização. Esse saber mais vincula a audiência ao espetáculo, mobiliza uma participação mais completa com todos os recursos disponibilizados em cena.

Na cena I, do ato III, temos um exemplo dessa convergência. Viola e Olívia se encontram em um jardim da condessa. Cesário-Viola vem em nome de outro, de Orsino. É um atravessador da sedução do Duque de Ilíria. Olívio não quer saber de Orsino, do outro, mas sim deste, de Cesário-Viola. Essas cadeias abertas, como no poema 'Quadrilha', de Carlos Drummond de Andrade, justapõem-se:

\section{VIOLA}

Então sigo o rumo do sol. Graça e paz acompanhem a senhora. Quer que eu leve algo pro meu amo? Then westward-ho! Grace and good disposition. Attend your ladyship!

You'll nothing, madam, to my lord by me?

\section{OLÍVIA}

Não vá, eu imploro. Fale o que você pensa de mim.

Stay:I prithee, tell me what thou thinkest of me.

\section{VIOLA}

Que você pensa que não é o que é.

That you do think you are not what you are.

\section{OLÍVIA}

Se penso assim, eu penso o mesmo de você.

If I think so, I think the same of you.

VIOLA

Então a senhora está certa: Eu não sou o que eu sou.

Then think you right: I am not what I am.

\section{OLÍVIA}

Quem me dera que você fosse como eu quero.

I would you were as I would have you be!

\section{VIOLA}

Isso seria melhor, madame, do que eu sou? Que assim fora, pois agora sou o teu bobo. Would it be better, madam, than I am? I wish it might, for now I am your fool.

Assim, o disfarce não oculta nada. Tudo precisa ser mostrado. O esconder é uma demonstração do revelar, de focar algo. Daí a teatralidade ostensiva da dramaturgia de Shakespeare, explorada intensamente em suas comédias.

Viola esconde sua identidade. Ela chega ao estranho reino de Ilíria, uma terra fantásti- 
ca onde as pessoas se entregam a ouvir canções tristes,cair em amor instantaneamente, armar brincadeiras pesadas e encher a cara ${ }^{11}$. Na cena dois do primeiro ato, tudo isso é performando para o público. A naúfraga abonada vai entrar para o serviço do duque, para conhecer esse estranho país, para nos fazer conhecer o mundo representado. Para nós que tudo observamos, Viola é uma mulher disfarçada de homem. No tempo de Shakespeare tal jogo era ainda mais complexo. Era um jovem ator, fazendo o papel de uma mulher travestida de homem. De qualquer jeito temos um ator fazendo uma personagem que se disfarça. $\mathrm{O}$ ator é duplamente desdobrado como figura, no papel e na mascarada.

No decorrer da peça, Viola situa-se entre os amores de Orsino e Olívia (até o nome Viola é uma retomada de Olívia). Orsino vai aprender o que é amar por uma mulher vestido de homem; já Olívia que amou Cesário - Viola vai ficar com o gêmeo, o duplo de Viola. Em si mesmos os agentes não possuem a habilidade de perceber que os eventos são maiores que seus partícipes, uma clara imagem que espetáculo é maior que as personagens. Paradoxo aparente de uma dramaturgia cômica, pois, na verdade, os agentes contribuem mais para o conhecimento do espetáculo que de si mesmos. Nisso se aproximam das marionetes, como figuras que dentro do espaço de sua exibição realizam os atos mais diversos por que podem, por que são bonecos. E não se pede deles nenhuma explicação. E quando a explicação é apresentada, ela tem a lógica daquilo que é mostrada: é uma lógica performativa, a lógica de um espetáculo como espetáculo, que justifica a si mesmo a partir de suas escolhas.

As falas do bobo valem-se dessa manipulação de uma expectativa de coerência. Elas se parecem com enigmas ou sentenças filosóficas. Há interpenetração do cômico e do sério que chega a desorientar mesmo a audiências. Esses enigmas não são profundos mistérios. Tudo que vem à cena tem sua dimensão de superfície, de exibição. Na verdade, como os duplos e disfarces, as falas do bobo são jogos que se aplicam imediatamente ao que está acontecendo, expondo a limitação de conhecimento dos outros agentes. Para entender, é preciso decifrar interpretar. E não há tempo: o bobo, como uma metralhadora, engata uma associação em outra. Há um desperdício em tudo isso. Uma coisa é ler o que o bobo diz. Outra coisa é ouvir e ver o bobo falando. A palavra nos remete para algo fora da linguagem. Sua complicação vem de seu arranjo. A relevância da organização, da disposição das palavras, da sintaxe do dito, da enunciação vem em primeiro lugar. Como o disfarce sobre a personagem. O que se mostra, o espetáculo é evidenciado nisso. As habilidades de refazer os sentidos através de configurar os materiais são focadas. Nisso, a figura do bobo retoma uma tradição dos sonhos, profecias, presságios e outras modalidades de atos e agentes que, em teatros com recursos mínimos, produziram seus efeitos por meio por performances que expunham sua teatralidade, o nexo entre teatralidade e limites/possibilidades de entendimento.

11 EPSTEIN, N. Friendly Shakespeare. Penguin Books, 1993 


\section{3 - Tróilo e Cressida: Dramaturgia e Montagem ${ }^{12}$}

A peça integra o chamado grupo de peças-problema (Tróilo e Créssida, Bem está o que bem acaba e Medida por Medida), classificação esta que agrupa peças com questões abertas quanto ao gênero, entre outras dificuldades. Em nosso caso, Tróilo e Cressida (1602) nas primeiras edições aparece sucessivamente como drama histórico, comédia e tragédia. A indeterminação do gênero coloca em questão uma pretensa unidade da representação em Shakespeare e, decorrente disso, em grandes dramaturgias. A impossibilidade desde cedo de a peça se reduzir a uma etiqueta unívoca nos incita a acompanhar mais de perto o espetáculo para o qual o texto provê materiais.

Primeiramente, a macro-estrutura, a divisão em partes. O primeiro ato assim se configura:

\section{Prólogo}

Cena 1- Tróia. Externa. Proximidades do palácio de Príamo

Cena 2- Tróia. Externa. Proximidades do palácio de Príamo

Cena 3- Acampamento dos helenos, fora da cidade de Tróia.

O prólogo é performado por um agente de ambivalente estatuto: primeiro, a cena é um destaque do resto do espetáculo, pois este personagem isolado cujo nome é sua função- Prólogo - função que se esgota durante sua presença em cena, pois o agente não mais retornará ao palco; segundo, ampliando este destaque, o agente após, inserir a audiência nos eventos representados, por meio de um sumário do espaço e de alguns antecedentes da trama homérica, dirige-se abertamente aos espectadores, evidenciando a metateatralidade de performance. Ou seja, o prólogo do Prólogo divide-se em duas partes: de uma panorâmica apresentação de cenários, figuras e acontecimentos para a ênfase na interação, nas expectativas dos eventos que serão ainda representados. A mudança do amplo enfoque retrospectivo, que incide sobre eventos referidos mas não atuais, para o prospectivo, que parte da atualidade da audiência para um futuro aberto, está na auto-apresentação do prólogo, como alguém armado, orientando a audiência a conectar o espetáculo de agora com a tradição de peças com cenas de guerra, como Henrique V(1499). O destacado prólogo arremete-se para uma ambiência de guerra, por meio do mapeamento lugares de batalha e enumeração de belicosos e valentes lutadores, bem como as razões da disputa e as disposições dos espíritos em animosidade para ser interrompido abruptamente com o deslocamento do foco de atenção para quem observa os eventos narrados. Assim, um ritmo ágil, apressado, urgente encaminha a abertura do espetáculo para a cena seguinte. $\mathrm{O}$ armado prólogo demanda potenciais beligerantes respostas.

Ao mesmo tempo, no que o prólogo se apressa em dizer, alonga-se em silenciar: não ouvimos nenhum nome dos que posteriormente vão protagonizar a obra. As amplas di-

12 Escrito em 30/04/2007. 
mensões da guerra e a imediata relação com a platéia são eventos conjugados sem que sem se vislumbre quem estará envolvido no centro dos acontecimentos encenados. Disto, esta ausência também desdobra em nova ausência: não só os protagonistas como também suas situações, seus encontros e desencontros são referidos. O Prólogo fala da guerra, mas não fala dos que de fato vão guerrear. Assim, este anti-prólogo abre um espetáculo difícil de classificar, uma peça sem gênero, ou um anti-gênero teatral. O estranhamento, contudo, não se reduz ao prólogo do Prólogo.

Na cena seguinte, não há guerra: há uma personagem que integra a elite de Tróia (filho do rei Príamo) que não quer combater. Antes, ele se apresenta comparando-se aos gregos em hipérboles negativas cujo parâmetro invertido é o universo feminino: os gregos são mais hábeis, fortes, cruéis e valentes, e Tróilo é mais fraco que uma lágrima de mulher, menos valente que uma virgem na noite. É um conjunto de proporções: as qualidades do outro vinculam-se e culminam em total virilidade. Por outro lado, Tróilo, ao seu turno, é inversamente desmontado, desmasculinizado, até virar nem homem, nem mulher, mas um garotinho sem experiência alguma. Ao armado Prólogo, temos aquele que não quer lugar a premente guerra, que se desarma, que se dissocia daquilo previamente enunciado. Um príncipe não guerreiro em um estado de guerra, um príncipe que prefere um outro campo de batalha, o seu próprio coração.

Desde logo temos o entrechoque entre a primeira cena e o prólogo. É como se um espetáculo tivesse sido anunciado, prometido e um outro é representado. A performance de Tróilo nega a guerra. Tróilo nega a si mesmo como príncipe e membro da elite de um dos lados do conflito, nega a dimensão ampla da batalha previamente referida e atualizada no seu status, nas responsabilidades de um filho do rei em época de guerra. Nessa negação afirma-se a opção personagem de restringir sua vontade apenas em um afeto para uma mulher em particular.

Com isso, Tróilo redefine o espetáculo recém-iniciado. Sua atuação ao mesmo promove um evento em cena e reorganiza o que havia sido proposto como horizonte de longa duração da peça. Tanto para o evento de agora quanto para aquilo que virá, Tróilo é uma nova perspectiva do universo representado.

Esse ato anti-representacional, essa atuação contra o espetáculo em processo de fazer-se, determina para a audiência um reposicionamento daquilo que se performa. As expectativas de longo curso são em parte substituídas por ou associadas a expectativas de revisão, como se a cada nova cena o espetáculo projeta nova relevâncias. Assim, o que importava em uma parte é renegociado em outra. Com a sucessão, a instabilidade de uma continuidade de perspectiva unificante cede o um lugar para a estabilidade dos aspectos plurais em conflitos e interrelacionados. Trata-se de uma diferente maneira de montar, de estabelecer vínculos entre as partes. Cada uma delas é um evento que se apropria dos anteriores e estabelece sua recepção a partir da diferença, da transformação em presença do que era tido como norma. Dessa maneira, a norma, o padrão é a revisão, a intervenção modificadora das ações e dos agentes apresentados. 
Logo, o estatuto ambivalente dos agentes é a aplicação da lógica ambivalente da montagem. Pois as referências estão co-presentes, acumuladas. O Prólogo é e não é um arauto, está e não está no mundo representado. Tróilo é e não é um guerreiro, e um apaixonado. $\mathrm{E}$ assim as demais figuras em cena.

\section{4- A Quadratura do Círculo - A Comicidade em A Comédia dos Erros ${ }^{13}$}

Examinado A comédia dos erros de Shakespeare podemos encontrar elementos para uma explicitação mais pontual da teoria da comicidade a partir de sua produção. O que é engraçado nesta obra? Por que ela se propõe como cômica?

A situação dos duplos tem uma enorme tradição. Shakespeare mesmo apropria-se do texto de Plauto - dois textos na verdade, Os dois Menecmos e Anfitrião - e amplia o procedimento: temos dois duplos, um jogo de duplos de duplos.

Por mais incrível que pareça, a ideia de duplo não restringe à confusão que ela engendra. Ao mesmo tempo que aponta para uma divisão, uma separação, aponta para uma união, uma completude, como se vê no mito contado justamente pelo comediógrafo Aristófanes em $O$ banquete, Platão.

Estas tendências convergentes e divergentes, agentes estruturadores e desestruturados se cifram na figura do duplo. Logo, o duplo do duplo é uma pesquisa de seu limites e possibilidades .

Inicialmente é bom tem em mente que, como uma das obras da fase inicial de Shakespeare, A comédia dos erros não é um exercício juvenil, mas sim trabalho de um homem com seus trinta anos que morreria 20 poucos anos depois. Não se trata de 'tentativas teatrais, mas de uma obra consciente de seus meios.

E que a peça representa? Justamente a si mesma, seus procedimentos. A comicidade de A comédia dos erros está na exploração da sobreposição de lógicas parciais de explicação de um fenômeno de baixa ocorrência no mundo real: primeiro, dois irmãos gêmeos, separados por anos, encontram-se em uma cidade. Isso já é difícil acontecer. Pra piorar, cada um dos irmãos possui um servo, que são gêmeos entre si também. Este disparate é a base da comédia. Os erros, os equívocos, a fonte do prazer do espetáculo consiste em dilatar ao máximo o tempo de encontro dos dois irmãos. Para o espectador, a sequência dos eventos estabelece uma relação de assimetria com os agentes em cena: cada círculo em volta das personagens é posto em instabilidade frente ao irmão errando, agindo como ele mesmo, enquanto que a platéia assiste a expansão da assimetria entre os círculos. Explicando. Após um prólogo que projeta os protagonistas da peça, temos a exposição do padrão de contracenação assimétrica entre os personagens: um desconfiado Antífolo de Siracusa (A) chega na cidade de Éfeso, um porto comercial, com seu servo Drómio de Siracusa. (B). Tudo em ordem. Mas o servo sai e entra o servo (B') do outro irmão (A') .

13 Elaborado em 6/5/2006. 
Em cena temos A com B'. Eles não se conhecem, não tem intimidade, pertencem a mundos diferentes. Cada um age de acordo com sua própria compreensão. Nunca pensariam que estão diante de gêmeos idênticos. E a situação inversa é a mesma coisa - tanto para o senhor, quanto para o servo há uma completa perda de nexos além da aparência, daquilo que eles conhecem previamente. E é com esse conhecimento prévio que eles buscam controlam o que está acontecendo. E este esforço de explicar o que não se explicar vão ampliando o desencontro entre o que parecem ser o que são mas são outra coisa.

A falsa semelhança entre o gêmeo atual e o inatual provoca essa instabilidade referencial que é intensificada pela presença mesma daquilo se acredita ser o verdadeiro referente. É tão absurdo pensar que aquilo que está na frente um do outro seja outra coisa que, pois, a única solução é justamente intervir, forçar este que ali está a voltar a ser aquilo em que se acredita que ele de algum modo seja Assim, estabelece-se uma lógica, um padrão desvinculante, dissociativo entre os partícipes do pequeno mundo de Antífolo de Éfeso.

Da rua para a casa - este padrão de encontros/desencontros vai tomando conta dos espaços que Antífolo de Éfeso frequentava. Assim, mapeando seus hábitos, pessoas e lugares, o caminho reverso do irmão desfaz, refaz uma cotidianeidade. E não há descanso. Não se trata de um estrangeiro na cidade. É o estrangeiro igualzinho ao familiar. É o mesmo que é outro, mas que ninguém percebe para além da semelhança a causa de tamanha confusão. Na medida em que o padrão avançava mais sem poder explicar o que está acontecendo ficam todos em cena e mais cônscios não somente do padrão, mas dos procedimentos que unificam a representação ficam os espectadores.

Este deslocamento das coisas para sua organização, para sua redistribuição coloca em primeiro plano os atos mesmos de disposição daquilo que é mostrado. Na comédia não há intimidade: as personagens são figuras que projetam o movimento de sua materialização. Nós rimos porque percebemos aquilo que realmente determina as contracenações. Movemos as cordas desses bonecos e rimos por que são bonecos. A saturação de desestruturação explicita a estruturação mesma dos eventos. A comédia nos mostra que uma dada situação fundamenta-se em sua construtividade. O meio para tornar isso perceptível é aproximar nossa tendência à estruturação com seu contra-movimento presente no espetáculo. Enfim, a comicidade é uma educação em modos de se organizar o real.

\section{5 - Caos e ordem: a dramaticidade personativa de Rei Lear de Shakes- peare $^{14}$}

A cena de abertura de Rei Lear nos oferece a preciosa oportunidade de discorrer acerca das matrizes dramáticas que orientam a palavra rumo à cena. Preocupando-se com a recepção do que dramatiza, Shakespeare dispõe os eventos de maneira a configurá-los em determinada formatividade, mediação imaginativa que possibilita a interação entre

14 Este texto integra o livro Imaginação Dramática. Brasília: Texto\&Imagem, 1998. 
palco e platéia. Dispor os eventos é distribuí-los, arranjá-los sob uma forma, criando o que Hölderlin denominou ritmo de representação ${ }^{15}$.

Contudo, a descrição desta maquinaria intencional não objetiva substituir a peça por meio de uma abstração sistêmica. Explicitar a poética da obra teatral - eis nosso objetivo. O ritmo de representação se oferece como um conjunto de individualizações de certas tensões adotadas pelos personagens. $\mathrm{O}$ agente dramático percorre o caminho de radicalizar seu horizonte-base, ao mesmo tempo que contracena com as linhas diretrizes dos outros. Por meio de um princípio de economia compositiva, a extrema variedade de sucessão dos eventos se coordena ao contexto fundamental de sua validação. Desta forma, o rígido controle da representação, ao se adotar perspectivas complementares que se especificam, produz a coesão e a coerência do espetáculo, realiza a obra em seu próprio fazer. O ritmo aqui não é conceptual, é um medium. Senão, vejamos.

A cena de abertura de Rei Lear baseia-se na partilha do reino. Esta imagem-princeps solicita a imaginação de um vetor desestruturante, a atualidade de uma ruína que será pouco a pouco conquistada. A transferência do poder faz irromper o desequilíbrio de uma Ordem e sua consequente reordenação. Ou melhor, da presumida estabilidade de um reino emerge uma caoticidade que se alimenta dessa ficção de ordem. Em toda a peça a miragem de um cosmo cede à vigorosa realidade de uma destruição irremediável. Começa a peça já por sua estética de corrosão e a grande arte de Shakespeare será dar o tempo e o espaço dessa lógica às avessas, dessa lógica da iconoclastia, dessa verdade do que não é, do que tudo torna informe, que doa as formas e sentidos ao que, imediatamente, formas nem sentido teria.

E por quê ? Ao se individualizar horizontes de base que permeiam uma obra que desconstrói uma ordem, surge a inquietante interrogação a respeito de como figurar a desfiguração, ultrapassando as motivações sempre vivas de uma estética clássica, que toma dos princípios formais abstratos de harmonia, equilíbrio e verossimilhança seu alento e seu logos. Uma razão absoluta a priori, que buscasse enfeixar o fenômeno constituído e constituidor da peça em categorias-atos de eliminação do díspar e do contraditório, fatalmente soçobraria em suas estratégias de inteligibilidade. Não apreendendo a poética própria de Rei Lear, marcada pelo ritmo de representação que distribui em palco agentes como eventos personificadores de uma caoticidade, este cógito se verá hesitante e confuso, abraçando-se nos esqueletos externos do enredo - pensar a quitina para chegar ao cadáver...

Mas vemos a partilha. Chega o rei e distribui seu reino, como o espetáculo distribuirá as tensões. Assim como cada parte guarda uma relação com o todo Imperial, cada tensão apresentada guarda e distende as matrizes dramáticas da peça. Contudo, a divisão do poder só realça a perda do reino, e não a justa e consequente resolução do que se apresenta. Uma outra linha de ação se sobrepõe à partilha. O mapa e as partes do mapa não

15 V. Holderlin Reflexões. A. Abrances (Org.)Relume-Dumará, 1994. 
correspondem às distintas e distinguíveis realidades das herdeiras. Uma delas, Cordélia, acompanha em seu apartes a transmissão das terras e as dissimulações que se encontram nos fatos. Contrariando os desígnios reais, ela, Cordélia, não acata a partilha, pois não compartilha dos mesmos desejos de suas irmãs.

A mais amada torna-se, em seguida, a mais odiada. Por uma inverossímil mudança em seu pathos, o rei troca a oferta por banimento, em um extremo de extremos que só se explica por que está implicado na estrutura de imagens de Rei Lear. Podemos afirmar que só uma excessividade pode fazer a mediação entre palco e platéia, concretizando, para além do que se vê - mas incondicionalmente relacionada com o que está - o grau de concreção e futuridade da peça. A temporalidade do teatro exige que se ultrapasse o isolacionismo dos fatos, fazendo com que cada evento singularize a tensão de base do drama. O que ocorre em cada momento da peça aponta para as matrizes assumidas no ritmo de representação que engendra a obra que se põe em cena. Figurando sempre uma presença, efetiva-se a especificação das tensões que de si mesmas mutuamente se conformam e se reenviam. A ira de Lear é ficcional, tal como a personagem, assumindo a descontinuidade que desbloqueia o acesso ao ritmo de representação. O mapa desfeito não cessa de ser rasgado. Irreversivelmente, temos a passagem da ordem presumida à desordem manifesta. $\mathrm{O}$ que veremos adiante será a explicitação das tensões que seguirão o curso de seu horizonte base.

Novamente. As personagem facultam para o espectador pontos de orientação. A viragem do pathos real ocasionará a reversibilidade dos acontecimentos. A mudança para com Cordélia indica uma nova situação para Lear. Confrontando os estados e suas transformações, o público é construído pela obra. A recepção participa atualizando o ritmo da representação.

Novamente ainda: esta mudança pontual faz convergir para as outras mudanças a intensidade de sua realização. Tão drástica como foi a viragem de Cordélia mais será a de Lear. Temos um conjunto de pontos implicados que se interligam na perspectiva ficcional que é revelada em cada evento. Conhece-se a peça ao se reconhecer a coerência da imaginação. Um mundo em movimentação, mesmo que seja para a sua instabilidade, passa a ser real diante de nossos olhos. A dinâmica imaginativa do espetáculo comanda sua compreensão. Cada personagem e cada evento encontram-se fronteiriços uns com os outros, limitando a si próprios e os restantes. Em cena, a individualização dos caracteres nos veicula o drama mesmo da obra em seu acontecimento e abertura, sua plasticidade originária e originante. Os finitos fictos necessitam do paradoxo de sua excedência para se promoverem como sentido e forma inteligíveis e imagináveis .

A palavra em muitas vezes explicita e explora esta maquinaria que se funda e que se autoregulamenta após. Nada - é só o que em meio a sua ira Lear fala. "Do nada, nada virá". Esta é emblemática divisa da peça, o sentido do sentido da poética do drama. A esta declaração, acrescenta-se a de Cordélia, ao fim desta longa abertura : "o tempo desvendará. Estas duas afirmações convergem para fornecer o horizonte interpretativo da obra. É 
preciso, para acompanhar o que surge por entre as cenas, uma sensibilidade que supere a localidade dos eventos e veja irromper, em cada momento, a emergência de uma diferenciação que, contida nos apelos breves de uma referência ou de uma resposta, sucumbe sem objeto e sem conclusão por entre o desassombro inexplicado e perplexo de uma vertigem sem nome. A fala do Rei conjuga-se com a profecia de Cordélia. A metamorfose dos acontecimentos desvela violentamente a desmesura que a tudo abarca. Próximo está de nós a abismática sombra que empalidece todos os projetos. Entre o querer e o efetuar, indeterminam-se as resultantes. O rigoroso ritmo de representação encontra seu telos no vigoroso contexto de sua vacuidade.

Termina esta longa cena de abertura com o diálogo das filhas que ganharam seu quinhão da herança paterna. Regane e Goneril direcionam as explosões de raiva do rei e a expulsão da irmã Cordélia - atos que lhe beneficiam - como surtos de uma mente doente, de uma razão que desfalece. Este artifício faz notar a convergência da interpretação dos eventos para uma perspectiva individual. O que acontece sempre o é para alguém e no conflito de interpretações nasce a derrocada de uma ordem de sentido estável. Como os abutres despedaçando o já morto, elas induzem o encaminhamento dos fatos para a justificativa de suas próprias prerrogativas que assim e desse modo ganham veracidade em função de sua coordenação ao estatuto de seu discurso-base. O espectador se vê diante da verossímil inverosimilhança do mal tornado presença em palco sem que dele se compadeça. Esta amoralidade estética é mais do mera visão de mundo. Temos aqui as estratégias personativas que exigem de cada personagem sua individualização e sua contracenação. As duas irmãs profetizam a figura de Edmundo, aparente subdrama do espetáculo.

É o que vemos na segunda cena deste primeiro ato. A sós, outra família, outro palácio, problemas próximos aos de Lear acontecem. Estas duas famílias como duas esferas que se tangenciam em sua cosmografia, fornecem um jogo de similitudes que pode se descrito dessa maneiras: Lear-Glócester, Cordélia-Edgar, Regane e Goneril-Edmund, reduplicação que vai além da analogia e da metáfora.

Este jogo de similitudes efetiva a economia expressiva da peça de forma a propositar cada momento do espetáculo na sua exata tensão. Algumas ausências se remetem para outras presenças, perfazendo a multirreferência dos espaços preenchidos. Tudo submete-se ao contínuo esforço de intensificação e diferenciação que se cria. Se antes, no tempo da dramaturgia ática clássica, o dramaturgo dispunha de um estoque de referências oriundas das memórias míticas e lendárias, agora, nessa modernidade que se forma e constrói, a peça mesma vai ter de fornecer um campo de identificações para o espectador. Estamos longe do autofechamento formal e abstrato das vanguardas, mas situados na autorepresentação do espetáculo como tal. Como conhecer sem um horizonte para o saber ? Este é configurado na dinâmica do ritmo de sua representação, as linhas de tensão inscritas no espaço tempo de sua realização. O espectador tem a impressão de estar vendo o que acontece e o que acontece parece ter surgido ali, diante de seus olhos. Ele mesmo relaciona e une os fios de inteligibilidade que pode pegar com suas mãos, tecendo a su- 
cessão, entretecendo a ilusão cênica. No jogo de similitudes pode-se aprender por uma diferença que surge por entre as malhas tecidas para serem trançadas, mesmo já estando terminado o vestido. Doce ironia...

Eis Edmund contraponto de Goneril e Regane, em cena como as duas antes terminaram sua anterior presença: um estar a sós consigo e com os espectadores, no qual apresenta seus planos, explicita-se, o que fará mais e sempre. Para quem monologa Edmund senão para a própria cena, como forma de tornar palpável visível e audível sua específica posição no espetáculo ? Não se trata de fluxo de consciência. Aqui não há imagens mas as razões de seus atos, o predicado definidor do sujeito. O bastardo sobrepujará o legítimo - eis seu lema. Contemporâneo de sua ânsia de poder é o incremento de sua subjetividade. E para dramatizar esta gradação são necessárias formas e fases. E qual recurso senão o decurso de uma transferência de responsabilidade, uma dissimulação que simula um revelar? Em seu diálogo com o pai, da mesma maneira que temos a dupla realidade de injusto e justiceiro, na figura de Edmund, temos a dupla recepção espetáculo divido entre a perspicácia do filho e a ignorância de Glócester. O público bem vê como esta ficcionalização ganha sua própria verdade, pois o que se vê é a justaposição duplicadora de realidades num mesmo espaço. Ele sabe que a dualidade é unificada no ato mesmo de sua legibilidade concretizada em palco. As ambivalências tem a intenção de recolher a descontinuidade fundamental de todas as coisas e dar às mesmas os instrumentos de sus repertorização. Edmund engana só o pai, mas evoca a dupla vivência possível de um princípio monológico. Aqui e nestes tempos, as ambivalências são determinadas, disseminam-se como os raios de uma estrutura que medeia os acontecimentos. Mesmo a ambivalência mais pessoal - sua intimidade - é compreensível em função da razão construtiva da obra. A ficção não é um engodo que esconde as artimanhas da subjetividade em sua aporia narcísica. $\mathrm{O}$ ego é um espetáculo que morre como todos os espetáculos do mundo, como morre a própria arte. Os signos do mundo guardam e aguardam pela competência que os engendra.

Edmund dissimula e realça este dissimular que esconde o que não é. Utilizando-se do disfarce de uma incorpórea verdade ( a mentira), ele seduz o pai. Sem provas senão a desse show de mágica do qual tira do que não existe a precária existência de uma condenação, ele garante seu acesso à confiança do pai e se legitima como veículo para os futuros fatos. Edmund é um simulacro e, como todos os simulacros, segundo Shakespeare, cairá por terra, expostos no limite de sua excessividade que demonstra sua imponderabilidade. Aqui não ha lugar para absurdos. Ainda para Shakespeare o real é real e ficção é ficção, longe de nossa neurótica desmedida inglória. O que faz Edmundo não é ficção mas o sonho do sujeito que a maior realidade do mundo decepará.

Mas enquanto isso ... Glócester, seduzido, acusa os céus pelos transtornos na terra, antecipando o ritmo cósmico que será avistado na tempestade que ora se aproxima, mas já irrompeu no louco coração dos homens. Vaticinando estes novos tempos, os momentos de um mondo às avessas, tipicamente pós-renascentista no qual o natural e o cultural, 
frente aos conflitos de sua inteligibilidade, após a quebra da episteme teológica medieval, Glócester só consegue balbuciar: 'é estranho'. A estranheza se dá no desencontro de um homem com seu mundo, e na sintomática ausência de um fator absoluto de explicação de tudo o que é ou existe. Exacerbando este contexto, além dos conflitos, temos a desestruturação dos valores, signos das ordens constituídas e que acabam de ruir. O que antes era tido como válido, frente ao longo tempo de sua duração, encontra um novo uso, uma nova materialidade que não consegue suprir o passo que se arrasta. O estupor de Glócester é o entrechoque das épocas em um presente sem futuro, que será radicalizada e corporificada na loucura do Rei. A ordem real louca é a viragem final.

Sai Glócester e quem fica só ? O nosso agora não dissimulado Edmund. Ele converte a estranheza do pai em excelente loucura do mundo. Mobilizando os conflitos e as disparidades para si, a si mesmo evidencia como norma e diretriz para os cadáveres sem sentido do cosmo em crise. Aposta na ação subjetiva que remonta para a eficiência dos projetos individuais como maneira de se sobreviver aos destroços sem sentido do que já não é. Edmundo é a garantia de um presente reduzido a um futuro circunscrito à pendência de um resultado. Se tudo der certo, Edmund certo se apoderará do que quer. Eis aqui a denúncia de uma subjetividade cativa de sua persuasão desde que se compartilhe a egolatria. Edmund só vencerá entronizando em cada um o ego ditatorial de uma verdade sem questionamento. O poder só avança pela negação dos limites, e o maior dos limites e o maior dos esquecimento está no si-próprio.

A saída de Glócester aponta para a entrada de Edgar, o irmão de Edmund. A presença de Edgar retoma a ausência do pai Glócesteser quanto ao controle dos sentidos operado pelo bastardo Edmundo. Esta lógica implacável da distribuição dos conflitos e dos afetados pelo conflito efetiva a eficiência do jogo de similitudes proporcionador das diferenças, da individualizações postas em cena. Criando a memória do espetáculo, este jogo agora é transposto das esferas da famílias para o interior delas. O que se vê é a instauração de uma ordem frente a outra que se arruína. Esta ordem terá a justa medida e o real delineamento de seu programa-base. Edgar ignora, como seu pai, o imperioso voluntarismo de Edmundo e este dos dois se utiliza. Não há poder sem sujeitos: os que se assujeitam e os que manipulam a partir de sua aparente impessoalidade. Ao fim deste encontro com seu irmão, Edmund resume o espetáculo em que atua: um pai crédulo e um irmão nobre, tudo modelado a seus modo e bom tudo lhe parece assim. $\mathrm{O}$ mundo às avessas aguarda sua resolução. A dissimulação de Edmund, contemporânea e homóloga a das filhas de Lear, revelar-se-á como astúcia que denuncia quem delas se serviu. No imaginário de Shakespeare as ambivalências se determinam até o fim da peça. A variação encontra seu complemento que as emenda. A lógica da imaginação shakesperiana doa a verdade dos projetos. Tudo é construído e significado, até o próprio caos. Edmund é um mal que encontrará a futuridade correlativa de sua imposição como figura no mundo da obra.

Após, cinematograficamente, a peça conduz-nos para tornar a ver Lear. Aqui encontra-se ele diferentemente. Cada visagem sua corresponde para o espectador uma alte- 
ração sugerida e concretizada pelo ritmo de representação do espetáculo. Os cortes e o tempo novo da cena dramatizam o seguir e o diferenciar deste ritmo. Os novos elementos agem como intensificação e valência da obra em sua especificidade. As cenas presentes desdobram o jogo de similitudes praticado. A ordem representacional surge como iluminação deste movimento que de si mesmo solicita o seguir, o ofertar e o perceber. Os cortes abruptos e as personagens individualizam, demarcam os campos de atividade na atualidade de suas respostas ao fazer-se da obra. Tornamos a ver Lear e ele não está só e já não é mais o mesmo, sendo Lear.

$\mathrm{O}$ que agora faz a diferença é a emergência do personagem Bobo. Sem nome e sem passado, identificável apenas pelas suas falas e sua relação com o rei, o Bobo é a irrealidade palpável de um parasitismo sem substância. De si mesmo não existe: necessita de Outro. Para este, revela o sentido dos acontecimentos bem como a intimidade desconhecida do hospedeiro. Para tanto, usa de uma linguagem cifrada da qual não dá a chave do código. Parodiando seu alvo-Outro, não resolve e nem se envolve com o que anuncia em suas canções, advinhas, danças, mímicas e apotegmas. Distende-se como Outro deste Lear, como sem nome e sem laços, tão distante como a percepção dos fatos e do autosaber do rei. Sua consciência é uma razão que não arregimenta para si os dividendos egolátricos do saber. Ele é a não-pessoa da peça, paradoxalmente contraposto a Edmund. Vê-se como a peça constrói-se com atos personativos que oferecem vários níveis convergentes e complementares de realidade. Do nada, nada virá, disse Lear e a profecia se cumpre, também no Bobo. Ele é uma figura sem persona, só existe pela cena, por Lear. Como duplo do rei, o Bobo reúne e torna intransitivos os nexos dos fatos. Como operador ficcional da peça, reivindica para si o olhar que pratica a imaginação e a reconhece como ficção. Os outros personagens individualizam o ritmo da peça, individualizando-se; o Bobo configura o ato da obra como ficção, mostrando como é feito um personagem. Sua pseudo-ingenuidade repercute a verdade da imaginação como fazer intencional e perceptível como tal. Nada de psicologismos: o Outro aqui é uma ciência operativa que não se reduz em conceitos. A imagem-Bobo se oferece como conhecimento das marcas restritivas da formatividade dinâmica da imaginação dramática posta em ação. Imaginar é engendrar, é circunscrever. Criar é limitar.

Esta desconstrução de Lear ofertada pelo Bobo reverbera o descentramento da figura do rei já sem castelo. Este deixar de ser que será experimentado com toda a sua veemência por Lear, acopla-se à impessoal figura do Bobo. Acompanhando Lear (e nós seguindo o bobo), veremos a dramatização de uma ontologia característica na qual aquele que já não é, e deixa de ser, é. Este diagrama de forças de uma despersonalização personificante acompanha as origens do próprio teatro. Por isso, desde seus princípios, a arte dramática representou personagens para a morte. A morte, este terrível-grande-nada, agencia os comportamentos mais diversos. Para ela se encaminham os atores, tornando concreta e sensível, a realidade do que se não vê. O chamado 'heroísmo trágico' é o de um inexplicável acatamento da finitude que conclama e devora os membros do mundo. Inexoravel- 
mente preso a esta destinação, caminham para a morte e ela, em sus rostos e clamores ou na paz de um rosto sem face, faz-se presente. Captar essa atualidade imaterial que só se vê por mediação - eis uma tarefa à qual se dispôs o teatro. A loucura do rei e a morte trágica dos heróis da raça se oferecem como situações-limite que colocam o horizonte definidor da maquinaria dramática. Trabalhando com uma ontologia pontual, na qual atua o instante de um entre-estado, a cena aponta para a recepção do existencialismo de uma específica. imaginação. Esta imaginação dramática nos proporciona os meios possíveis para se atingir este movimento ontológico que ajusta, em um mesmo tempo e espaço, a modificação de algo que é a partir dele mesmo. A cena, e as artes dela derivadas, originou-se como extensão e exposição de nossa indiviso modo de nos significar e finitizar. Lear É, no extremo de sua pendência, sem deixar de ser em seu arco-nada. O teatro dramatiza-se ao colocar em palco a figura de Lear. O conhecimento dessa ontologia pontual transforma a imaginação em operador de nossa finitude, vista agora sem desespero, mas aprendida e compreendida em sua potência plástica.

Por isso, isso ecoam uma memória dramática na fala do Bobo quando mostra quem Lear é: a sombra de Lear. Estes elementos indiciais - sombra, fumaça, cicatriz- renovam e projetam a sensibilidade receptiva que trabalha com estruturas autônomas de sentido que preconizam a participação de um sujeito. Não sendo nem realidades acabadas nem informes anuências de uma ausência sem telos, os signos indiciais corroboram a natureza perceptiva do teatro e sua relação complexa com os eventos. A constituição do sujeito-receptor se faz, complementarmente na construção do espetáculo. Dois que não são em sua totalidade se tornam no fazer da peça. O fantasma de Lear não assombra, mas assoma. 